eCommons@AKU

July 1996

\title{
Fulminant hepatic failure in pregnant women: acute fatty liver or acute viral hepatitis?
}

\author{
S S. Hamid
}

Aga Khan University, saeed.hamid@aku.edu

S M. Jafri

Aga Khan University

H Khan

HShah

Aga Khan University, hasnain.alishah@aku.edu

Z Abbas

Aga Khan University, zaigham.abbas@aku.edu

See next page for additional authors

Follow this and additional works at: https://ecommons.aku.edu/ pakistan_fhs_mc_med_gastroenterol

Part of the Gastroenterology Commons

\section{Recommended Citation}

Hamid, S. S., Jafri, S. M., Khan, H., Shah, H., Abbas, Z., Fields, H. (1996). Fulminant hepatic failure in pregnant women: acute fatty liver or acute viral hepatitis?. Journal of Hepatology, 25(1), 20-27.

Available at: https://ecommons.aku.edu/pakistan_fhs_mc_med_gastroenterol/192 
Authors

S S. Hamid, S M. Jafri, H Khan, H Shah, Z Abbas, and H Fields 


\title{
Fulminant hepatic failure in pregnant women: acute fatty liver or acute viral hepatitis?
}

\author{
Saeed S. Hamid, S. M Wasim Jafri, Haleem Khan, Hasnain Shah, Zaigham Abbas and Howard Fields \\ Department of Medicine, The Aga Khan University Hospital, Karachi, Pakistan and Center for Disease Control, Atlanta, USA
}

\begin{abstract}
Background: Hepatitis $\mathbf{E}$ virus, which is endemic in our region, can cause severe liver dysfunction in pregnant women and this can be clinically confused with acute fatty liver of pregnancy.

Methods: We studied the clinical and laboratory data as well as the maternal and fetal outcomes of 12 pregnant women presenting with fulminant hepatic failure in order to determine the etiology of the disease. The clinical diagnoses were subsequently correlated with serologic assays for acute HEV infection. All patients were severely ill with deep jaundice, grade 3-4 encephalopathy and abnormal prothrombin times.

Results: A clinical diagnosis of acute viral hepatitis was made in nine patients and of acute fatty liver in the other three cases. IgM and IgG antibodies confirmed acute viral hepatitis $E$ in six of
\end{abstract}

Severe liver dysfunction in late pregnancy is an $\mathcal{N}$ unusual but dramatic event because it can progress very rapidly to fulminating disease and also because two lives, that of the mother and fetus, are involved. The important causes of such an event are acute viral hepatitis, acute fatty liver of pregnancy, pre-eclampsia related liver disease, tetracycline induced liver damage and the "HELLP" (Hemolysis, Elevated Liver enzymes and Low Platelet count) syndrome (1). Amongst these, acute viral hepatitis (AVH) and acute fatty liver of pregnancy (AFLP) are the commonest and can be clinically confused with each other.

Acute hepatitis during pregnancy can occur with any of the hepatotropic viruses. However, with regard

Received 13 June; revised 17 October; accepted 27 November 1995

Correspondence: Dr. Saeed Hamid, MRCP (UK), Assistant Professor, Department of Medicine, The Aga Khan University Hospital, Stadium Road, P.O.Box 3500, Karachi, Pakistan. Tel: (21)-4930051. Fax: (21)-4934942. the nine patients while one had acute hepatitis A infection. HEV IgM and IgG antibodies were, however, also positive in two of the three patients thought to have acute fatty liver. Maternal and fetal mortality were $16.6 \%$ and $50 \%$, respectively. Conclusions: We conclude that hepatitis $\mathrm{E}$ is the usual cause of acute liver failure in our pregnant women and that clinical and laboratory features do not permit accurate distinction between acute HEV infection and acute fatty liver of pregnancy. The prognosis in patients with acute HEV infection is much better than in other groups with severe liver failure (mortality 16\% vs $68 \%$ ).

Key words: Acute fatty liver; Fulminant hepatic failure; Hepatitis E; Pregnancy.

to pregnancy, acute hepatitis $\mathrm{E}$ virus (HEV) infection is of most interest as it can assume a fulminating course in a high proportion of pregnant women $(2,3)$. Pakistan is situated in a region where enterically transmitted non-A, non-B hepatitis, which includes hepatitis E, is endemic (4). However, due to the nonavailability of a serological test for HEV, accurate epidemiological information regarding this virus is not available from our country.

It is important to be able to differentiate between severe acute viral hepatitis and AFLP for three reasons: (a) The epidemiology of both diseases needs to be defined in pregnant women in our region, (b) Treatment options may be different, as prompt termination of pregnancy is usually required for improving prognosis in acute fatty liver (5), and (c) long-term prognosis may be different in both groups, with recent reports suggesting the AFLP can recur in subsequent pregnancies (6). However, there are limitations to accurate diagnosis of both conditions e.g. reliable and reproducible serological tests for the 
diagnosis of acute HEV infection are not widely available and a liver biopsy, which is often essential for the accurate diagnosis of AFLP, is usually not possible because of the gross coagulation derangements in these patients. Physicians are therefore usually left with formulating a diagnosis based on clinical and laboratory parameters. Although certain features are thought to be distinctive of either AVH or AFLP $(6,7)$, there is overlap in a number of parameters, making a confident clinical diagnosis difficult in many instances.

We report a descriptive study of pregnant women presenting with severe liver dysfunction. Our aims were: (1) to study the clinical, biochemical and serological profile of these patients in order to determine the etiology of the disease; (2) to correlate our clinical diagnosis in these patients with the serological tests for $\mathrm{HEV}$; and (3) to determine the maternal and fetal prognosis in these patients.

\section{Patients and Methods}

During a 3-year period from July 1991 to July 1994, the total number of deliveries at our hospital was 5935 . Of these, 52 patients $0.87 \%$ developed jaundice during pregnancy. Although complete data are not available in some cases, 30 of these 52 patients were considered to be suffering from acute viral hepatitis, the other diagnoses made being intra-hepatic cholestasis of pregnancy in ten, chronic viral hepatitis in three, HELLP syndrome in three, cholelithiasis in three, and other infections in three (Dr. Aliya, unpublished data).

Twelve of these 5935 patients $(0.2 \%)$ presented to hospital in fulminant hepatic failure (FHF), which is defined here as progression to hepatic encephalopathy within 15 days of the onset of jaundice in the absence of known previous liver disease (8). The encephalopathy was graded according to the standard classification from grade one to four (9). In only two patients was the pregnancy being supervised by medically trained persons while all others were being seen at home by dias (traditional birth attendants). All patients were managed in an intensive care unit setting and according to standard recommendations for the conservative treatment of FHF. Briefly, the treatment measures consisted of nursing patients at $20^{\circ}$ head-up tilt, early use of mannitol provided renal function was normal, aggressive lactulose therapy, maintenance of blood sugar levels by $10 \%$ dextrose infusions, prophylactic antibiotics and mechanical ventilation in cases of respiratory distress. Liver tests including serum bilirubin, alanine aminotransferase (ALT), alkaline phosphatase, serum albumin and pro- thrombin times were checked serially. Other biochemical laboratory data were recorded, including blood sugars, serum creatinine, electrolytes and serum uric acid. Hematology profile included white cell and platelet counts and tests for disseminated intravascular coagulation (DIC). If the FDP levels were greater than $20 \mu \mathrm{g} / \mathrm{ml}$, APTT was 1.5 times the upper limits of normal and platelets were below 150,000 , DIC was diagnosed to be present.

Hepatitis A IgM antibody, hepatitis B surface antigen and hepatitis $\mathrm{C}$ antibody (2nd generation ELISA) were assayed in all patients. In those who were $\mathrm{HBsAg}$ positive, hepatitis B core IgM and hepatitis delta antibody (IgG and IgM) were also checked. All serological tests were done using ELISA assays from Abbott Diagnostics and read on a Quantum II analyzer. Sera stored at $-70^{\circ} \mathrm{C}$ were available from eight patients for subsequent testing (not available for patients $4,5,11$ and 12). The stored sera were processed by PCR for detection of HCV RNA, according to the methodology described by Beach et al. (10), and were also sent to Centers for Disease Control Atlanta, USA, where the HEV antibodies (IgM and $\operatorname{IgG}$ ) were tested according to the following methodology.

\section{HEV serology}

This was done with a newly developed EIA method (H. Fields, manuscript in preparation). The assay utilizes an artificial recombinant protein composed of multiple linear antigenic epitopes from ORF2 and ORF3 from both the Burma and Mexico strain of HEV on a single molecule. The assay format has been previously described (11). The EIA method used was shown to be essentially equivalent in sensitivity and specificity to a commercially available kit when used on epidemiologically well-characterized sera previously tested by Western blot (12).

\section{Results}

\section{Demographic and clinical features}

Table 1 shows the demographic and clinical features of our patients. Mean age was 25 years and twothirds of patients were multigravida. The majority had a low socioeconomic/educational background as assessed by the area of residence, the nature of the husband's job and basic education of the patient. All were urban residents from different parts of the city. Only two were being followed up in hospital for their pregnancies. Apart from patients 1 and 2, all presented during the third trimester around a mean of 32 weeks. Progression to encephalopathy from the onset of jaundice was rapid in most cases (1 week or less in 9/12 patients) and all but one progressed to grade $3-4$ 
TABLE 1

Demographic and clinical features of pregnant women with FHF

\begin{tabular}{llllll}
$\begin{array}{lllll}\text { Patient } \\
\text { no. }\end{array}$ & $\begin{array}{l}\text { Age } \\
\text { (years) }\end{array}$ & Gravida & $\begin{array}{l}\text { Duration of } \\
\text { pregnancy at } \\
\text { presentation } \\
\text { (weeks) }\end{array}$ & $\begin{array}{l}\text { Jaundice to } \\
\text { encephalopathy } \\
\text { (days) }\end{array}$ & $\begin{array}{l}\text { Max. grade } \\
\text { of enceph. }\end{array}$ \\
\hline 1 & 22 & 5 & 16 & 2 & 3 \\
2 & 21 & 3 & 19 & 7 & 3 \\
3 & 25 & 2 & 28 & 5 & 4 \\
4 & 35 & 3 & 28 & 8 & 4 \\
5 & 26 & 2 & 34 & 3 & 4 \\
6 & 26 & 2 & 32 & 4 & 2 \\
7 & 25 & 5 & 33 & 5 & 3 \\
8 & 30 & 2 & 35 & 6 & 4 \\
9 & 28 & 1 & 34 & 12 & 4 \\
10 & 22 & 1 & 34 & 10 & 4 \\
11 & 22 & 1 & 33 & 5 & 4 \\
12 & 18 & 1 & 40 & 2 & \\
\hline
\end{tabular}

encephalopathy. Vomiting was a common prodromal symptom but fever and abdominal pain occurred infrequently. There were no clinical features to suggest the presence of pre-eclampsia in any patient such as proteinuria, hypertension or edema. There was no history of jaundice in previous pregnancies in the multi-gravid patients. There was no significant history of recent drug intake in any patient.

\section{Laboratory features}

Table 2 shows the relevant laboratory features. All patients were severely jaundiced at presentation (mean bilirubin of $16.4 \mathrm{mg} / \mathrm{dl}$ ). In almost all patients who survived, the total bilirubin values worsened before they began to fall. A wide range of serum ALT levels was observed, from 114 I.U. per liter in Patient 10 to 4830 I.U. per liter in Patient 12. A significant element of cholestasis was present in most cases, as shown by a mean alkaline phosphatase value of 320 IU/l, although it is possible that minor elevations of non-hepatic alkaline phosphatase may occur in normal pregnancies. Prothrombin times were abnormal in all cases and in three were grossly abnormal at greater than $120 \mathrm{~s}$. Serum albumin levels were below normal in all except one and were markedly low (less than $2 \mathrm{~g} / \mathrm{dl}$ ) in three patients. On a peripheral blood film burr cells, along with fragmented red cells and polychromasia, were seen in five patients. Patient No. 6 had occasional target cells but no normoblasts or giant platelets. Blood sugars were low (less than 80

\section{TABLE 2}

Laboratory features of pregnant women with FHF

\begin{tabular}{|c|c|c|c|c|c|c|c|c|}
\hline $\begin{array}{l}\text { Pt. } \\
\text { no }\end{array}$ & $\begin{array}{l}\text { Serum bilirubin } \\
\text { at presentation } \\
(n=0.2-1.25 \\
\mathrm{mg} / \mathrm{dl})\end{array}$ & $\begin{array}{l}\text { Max. ALT } \\
(n=0-55 \mathrm{iu} / 1)\end{array}$ & $\begin{array}{l}\text { Max.serum } \\
\text { alkaline } \\
\text { phosphatase } \\
(n=28-124 \mathrm{iu} / 1)\end{array}$ & $\begin{array}{l}\text { Peak prothrombin } \\
\text { time } \\
\text { (control } 11-13 \mathrm{~s} \text { ) }\end{array}$ & $\begin{array}{l}\text { Serum } \\
\text { albumin } \\
(n=3.2-5 \mathrm{~g} / \mathrm{dl})\end{array}$ & $\begin{array}{l}\text { Min. blood } \\
\text { sugar } \\
(\mathrm{mg} / \mathrm{dl})\end{array}$ & $\begin{array}{l}\text { Serum uric } \\
\text { acid } \\
(n=4.1-8 \\
\mathrm{mg} / \mathrm{dl})\end{array}$ & $\begin{array}{l}\text { White cell count } \\
\text { (at presentation) }\end{array}$ \\
\hline 1 & $12.9 / 3.1 *$ & 683 & 145 & 25 & 2.1 & 33 & $-* *$ & 15.8 \\
\hline 2 & $11.7 / 4.1$ & 1150 & 166 & 25 & 2.4 & 156 & 0.8 & 10.3 \\
\hline 3 & $19.7 / 8.4$ & 258 & 230 & $>120$ & 2.2 & 46 & - & 15.0 \\
\hline 4 & $14.5 / 7$ & 1053 & 350 & 52 & 3.0 & 71 & - & 15.4 \\
\hline 5 & $6 / 2.9$ & 2167 & 280 & $>120$ & 3.5 & 56 & 0.4 & 13.9 \\
\hline 6 & $29.6 / 18$ & 714 & 459 & 21 & 1.8 & 59 & - & 10.3 \\
\hline 7 & $22 / 7.5$ & 760 & 450 & 24 & 2.1 & 61 & - & 17.7 \\
\hline 8 & $18.7 / 10$ & 1588 & 375 & 34 & 2.2 & 48 & - & 15.7 \\
\hline 9 & $17.4 / 6.1$ & 118 & 320 & 33 & 1.7 & 11 & 2.6 & 23.2 \\
\hline 10 & $20 / 12.5$ & 114 & 110 & $>120$ & 1.8 & 31 & 4.9 & 29.1 \\
\hline 11 & $15.1 / 5.2$ & 262 & 643 & 57 & 2.5 & 97 & 5.6 & 20.6 \\
\hline 12 & $9.9 / 2.0$ & 4830 & 315 & 36 & 2.5 & 59 & - & 12.4 \\
\hline
\end{tabular}

* Figures show total and direct bilirubin.

** (-) indicates not tested. 


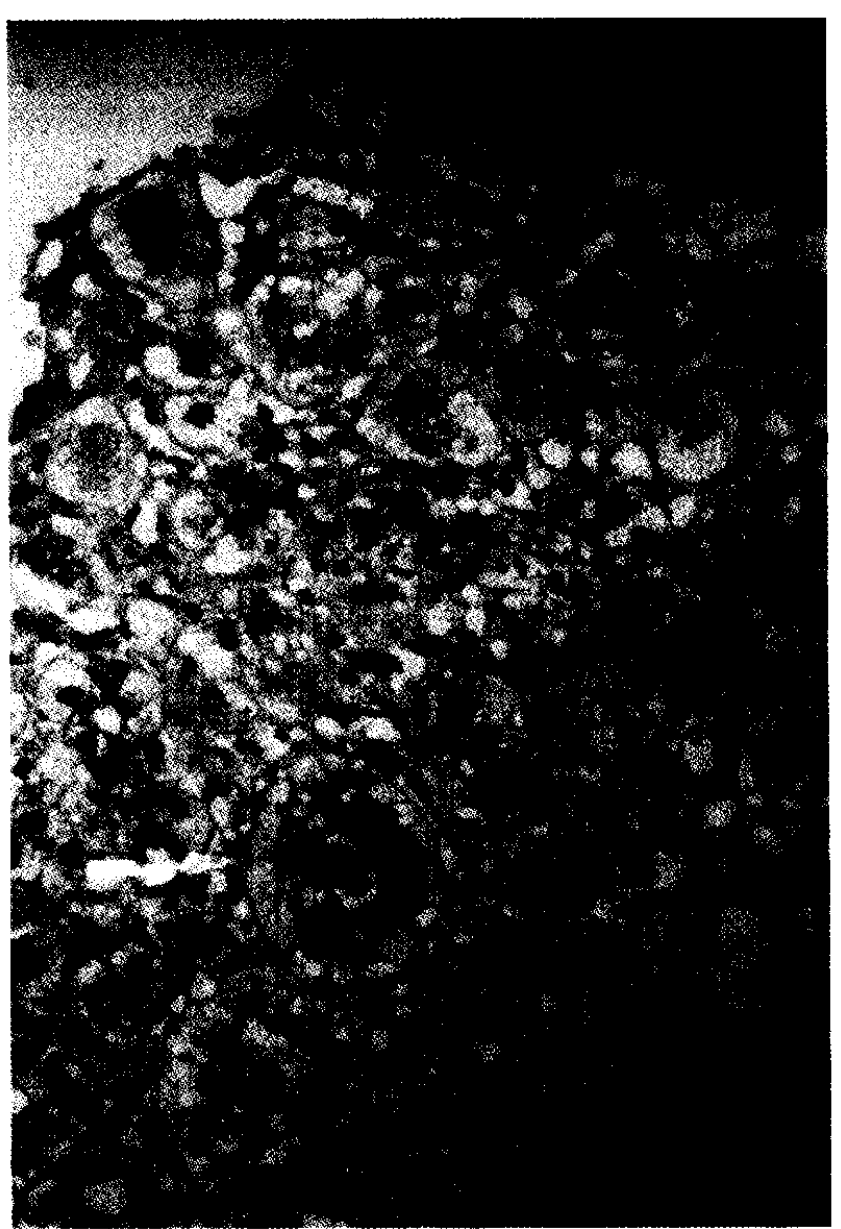

Fig. 1. High power view showing diffuse infiltration with chronic inflammatory cells, ballooning of hepatocytes, microvesicular fatty change (moderate degree) and arrangement of hepatocytes in an acinar pattern.

$\mathrm{mg} / \mathrm{dl}$ ) in all except two. Serum uric acid was measured in all the three patients diagnosed clinically to have AFLP (patient 9,10 and 11) and was found to be normal or just below normal. However serum uric acid was interestingly markedly low (less than $1 \mathrm{mg} /$ dl) in the two patients with AVH in whom it was measured. White cell counts were elevated (greater than $10^{9} / 1$ ) in ten patients and grossly elevated (greater than $20^{9} / 1$ ) in the three patients thought to have AFLP. Microbiologically confirmed infections were, however, found in only three patients (No. 3, 10 and 12) and these were urinary tract infections with E. coli in two and pneumonia with Strep. pneumoniae in the third patient. An ultrasound scan was done in all patients but did not show any evidence of obstruction or the presence of excess fat in any case. A CT scan of liver was subsequently done in the two patients clinically diagnosed to have AFLP (patients 9 and 10) and in both cases showed normal liver attenuation.
Hepatitis serology

Patient 12 was HAV IgM antibody positive, thus confirming acute hepatitis A infection (Table 3). All others were negative for HAV IgM and HCV antibodies. Patients 1 and 2 were positive for HBsAg but were negative for $\mathrm{HBc}$ IgM and HDV antibodies, suggesting that they were carriers of $\mathrm{HBV}$ and not cases of acute hepatitis B. All the eight available sera were negative for HCV RNA on PCR, thus excluding the possibility of acute $\mathrm{HCV}$ infection. All these eight sera were positive for $\mathrm{HEV}$ antibody IgM, confirming acute hepatitis $\mathrm{E}$ infection in these cases. All but one (patient 7) were also positive for HEV IgG antibody. Of the three patients diagnosed as having AFLP (No. 9, 10 and 11), two had sera available for further analysis (No. 9 and 10), and both were HEV antibody $\mathrm{IgM}$ and $\mathrm{IgG}$ reactive.

\section{Liver histology}

Only one patient (No. 5) gave consent for a liver biopsy. This was done during the same admission, as soon as the platelets and coagulation profile normalized. The liver architecture was preserved. There was diffuse infiltration with mainly chronic inflammatory cells but also some neutrophils, associated with ballooning and arrangement of hepatocytes in an acinar pattern (Fig. 1 and 2). This appearance has been frequently observed in cases of acute HEV infection (13). There was a moderate degree of microvesicular fatty change.

\section{Complications}

Five patients (No. 5, 7, 9, 10 and 11) developed renal impairment, as evidenced by a raised serum creati-

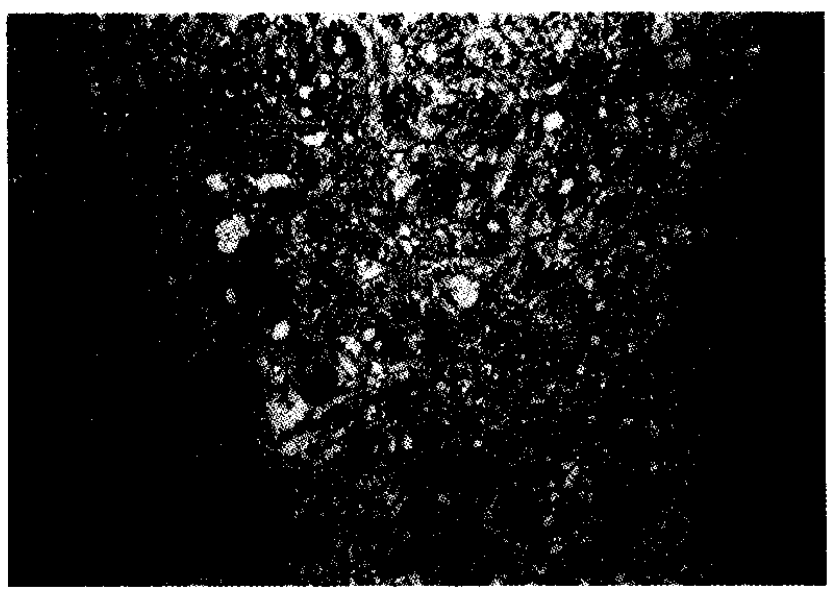

Fig. 2. Low power view shows intact liver architecture with diffuse inflammatory cell infiltrate in the lobules. Ballooning of hepatocytes with microvesicular fatty change and acinar formation is evident. 
TABLE 3

Hepatitis serology profiles of pregnant women with FHF

\begin{tabular}{|c|c|c|c|c|c|c|c|c|}
\hline \multirow[t]{2}{*}{ Pt. no. } & \multirow[t]{2}{*}{ HAV IgM } & \multirow[t]{2}{*}{ HBsAg } & \multirow[t]{2}{*}{$\mathrm{HBc}$ IgM } & \multirow[t]{2}{*}{$\begin{array}{l}\text { HDV } \\
\text { antibody }\end{array}$} & \multirow[t]{2}{*}{$\begin{array}{l}\mathrm{HCV} \\
\text { antibody }\end{array}$} & \multirow[t]{2}{*}{$\begin{array}{l}\text { PCR for } \\
\text { HCV RNA }\end{array}$} & \multicolumn{2}{|c|}{ Anti-HEV antibody } \\
\hline & & & & & & & IgM & $\operatorname{IgG}$ \\
\hline 1 & N. $R^{*}$ & Reactive & N. R. & N. R. & N.R. & Negative & Reactive & Reactive \\
\hline 2 & N. R. & Reactive & N. R. & N. R. & N.R. & Negative & Reactive & Reactive \\
\hline 3 & N.R. & N.R. & $-* *$ & - & N.R. & Negative & Reactive & Reactive \\
\hline 4 & N.R. & N.R. & - & - & N.R. & - & - & - \\
\hline 5 & N.R. & N.R. & - & - & N.R. & - & - & - \\
\hline 6 & N.R. & N.R. & - & - & N.R. & Negative & Reactive & Reactive \\
\hline 7 & N.R. & N.R. & - & - & N.R. & Negative & Reactive & N.R. \\
\hline 8 & N. R. & N.R. & - & - & N.R. & Negative & Reactive & Reactive \\
\hline 9 & N.R. & N.R. & - & - & N.R. & Negative & Reactive & Reactive \\
\hline 10 & N.R. & N.R. & - & - & N.R. & Negative & Reactive & Reactive \\
\hline 11 & N.R. & N.R. & - & - & N.R. & - & - & - \\
\hline 12 & Reactive & N.R. & - & - & N.R. & - & - & - \\
\hline
\end{tabular}

* N.R. indicates not reactive.

** (-) indicates not tested.

TABLE 4

Maternal and fetal outcomes in pregnant women with FHF

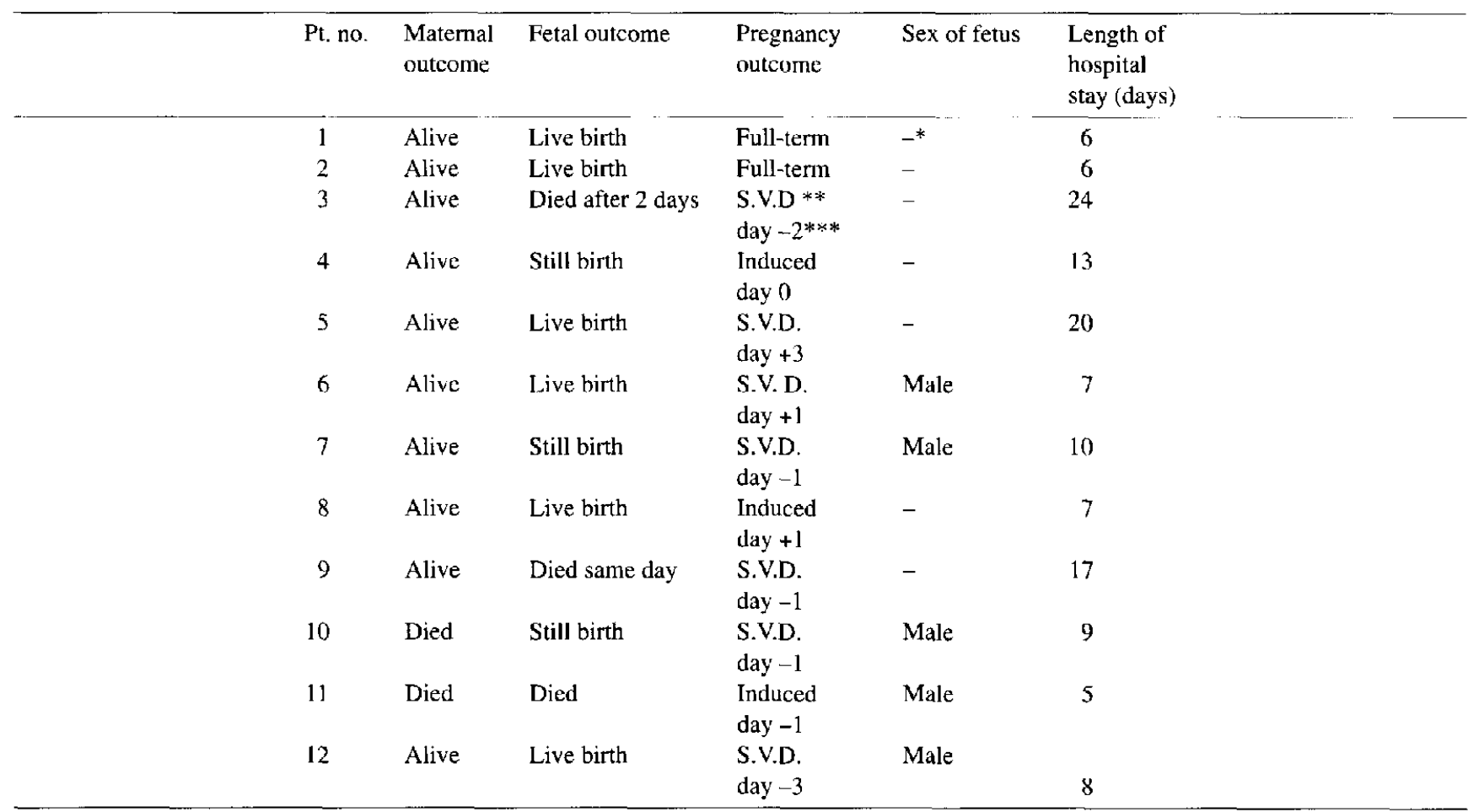

*(-) indicates not known.

** S.V.D. = Spontaneous vaginal delivery.

*** Day $0=$ Day of admission to our hospital.

nine (range 1.8 to $7.1 \mathrm{mg} / \mathrm{dl}$, normal up to $1.2 \mathrm{mg} / \mathrm{dl}$ ), but none required or were considered suitable for dialysis (patient 11). Evidence of DIC was present in seven patients and of these, six had significant post partum hemorrhage ( $\mathrm{PPH})$ requiring blood transfusions. Two of these patients also had upper G.I. bleeding. Four patients required mechanical ventila- tion for respiratory distress including the two patients who died.

\section{Maternal and fetal outcome}

Patients 10 and 11 died, giving a mortality rate of $16.6 \%$. The ten surviving patients have completely normal biochemical liver tests at follow up. One of 
these (patient No. 5) developed transient neuro-psychiatric symptoms. She had required an extended period of mechanical ventilation. One of the surviving patients has recently completed an uncomplicated full-term pregnancy, and another one is currently pregnant without any complications. The average length of hospital stay of approximately 12 days suggests that most patients got better quickly once they started to recover. Fetal mortality, however, was high at $50 \%$ with three still births and three deaths within 2 days of delivery. All deliveries occurred spontaneously, except two where induction with Prostaglandins or Syntocinon infusion was required. As can be seen in Table 4, the timing or mode of delivery did not seem to influence maternal outcome in this small group of patients.

\section{Clinical diagnosis}

On admission, patients 9,10 and 11 were diagnosed as having AFLP by the attending physicians. This was because they were all primigravida in the third trimester of pregnancy, the ALT levels were only moderately elevated (less than 300 IU/l) with significant cholestasis, there was evidence of DIC, all had marked leucocytosis in the absence of documented infection, and all developed renal failure. All these features are considered to be highly suggestive of AFLP $(1,5,6,7,14)$, although none are pathognomonic. However, in two of these patients (No. 9 and 10) the HEV antibody IgG and $\operatorname{lgM}$ was reactive, confirming the diagnosis of acute HEV infection.

The other nine patients were diagnosed as having acute viral hepatitis. Six of these were serologically confirmed to have acute HEV, while one had acute HAV infection. Although patient No. 3 did not have a marked elevation of ALT, other features suggestive of AFLP were missing.

\section{Discussion}

This study deals with acute sporadic HEV infection in pregnant women, causing FHF, and it highlights the challenges faced by the clinician in dealing with such patients, particularly in the setting of a developing country. The first challenge usually is to determine the etiology of the disease because subsequent management decisions may depend on this. The two diseases that can be confused with each other in this setting are acute viral hepatitis and acute fatty liver of pregnancy. The problem becomes even more relevant in areas where the different hepatitis viruses are endemic. Hepatitis $E$, in particular, causes fulminant cholestatic hepatitis in a high proportion of pregnant women (3).
In the majority of our cases the clinical diagnosis of acute viral hepatitis was correct and was subsequently confirmed by serological tests. However, our study suggests that in a number of instances, it may not be possible to distinguish clearly between AVH and AFLP. A number of well-defined clinical, laboratory and histological features have been described for AFLP $(1,5,6,7,14)$, but none are considered pathognomonic. Based on these criteria, three of our cases were diagnosed to be suffering from AFLP, but subsequent serologic testing proved a viral etiology in at least two of them. Hence some cases of acute HEV infection will be confused with AFLP, and vice versa. In the recent description of AFLP by Reyes et al. (6), a number of cases demonstrated a clinical and laboratory profile very similar to that of our patients with acute HEV infection and could easily have been diagnosed as having AVH if liver biopsies had not been available to support a diagnosis of AFLP.

Apart from an invasive procedure like a liver biopsy, some non-invasive investigations might point more towards AFLP than AVH if they are abnormal. For example, a significantly elevated serum uric acid level, usually associated with signs of pre-eclampsia, has been found in most patients with AFLP $(5,7)$. Also the demonstration of excess fat in the liver on a CT or MRI scan may be a valuable technique to establish the diagnosis of AFLP (15). A CT scan in two of our patients thought to have AFLP was negative for excess fat and could have helped in excluding this diagnosis. Our study supports a negative predictive value for CT liver in diagnosing AFLP.

Another approach would be the rapid diagnosis of acute viral hepatitis by employing a full battery of serologic tests. In Western countries, where HEV is rare, serologic tests for hepatitis $\mathrm{A}$ and $\mathrm{B}$ are readily available and should help clinicians to make a diagnosis relatively quickly. However, accurate and reliable serologic tests for HEV are not widely available. In particular, tests to detect IgM antibody to HEV remain largely research-based. IgG antibody tests are commercially available but will not distinguish between acute and past infection in areas endemic for HEV. PCR-based methods to detect HEV antigen in stool and serum have been described (16), but again these remain largely experimental and unrealistic due to excessive cost.

The second interesting point we noted in our study is the remarkably good prognosis of these seriously ill women on conservative treatment alone. Even though the disease became so severe, the maternal mortality was only $16 \%$. This clearly becomes meaningful when we compare it to mortality in our other 
groups with FHF. For example, during the same study period we admitted 26 other patients with FHF (20 males and six non-pregnant females) and the mortality in this group was $68 \%$ (70\% in males and $66 \%$ in non-pregnant women) (17). This substantial difference cannot be explained on any variations in treatment, as this was more or less according to a standard protocol, but could be explained on the differences in etiology because most patients who died had acute hepatitis B infection. Thus, although the disease may progress dramatically in pregnant women, the overall prognosis is better than for other FHF groups and the usual indicators of poor prognosis described in the literature may not hold true in these patients.

For example, if the criteria proposed by O'Grady et al. (18) for liver transplantation in FHF due to causes other than paracetamol poisoning were used, five patients would have been eligible for transplantation. This included the two patients who died (No.10 and 11) but also three other patients (No. 3, 4 and 5) who survived. Patients 3, 5 and 10 would have been eligible for transplantation on the basis of a prothrombin time greater than $100 \mathrm{~s}$. Patients 4 and 11 fulfilled at least three criteria for transplant, namely a non-A, non-B etiology, prothrombin time greater than $50 \mathrm{~s}$ and serum bilirubin greater than $300 \mu \mathrm{mol} / \mathrm{l}$. Our mortality is also low when compared to other reports of acute HEV infection in pregnant women $(2,3)$. However most of these studies deal with FHF in pregnant women during epidemics of HEV infection, whereas we report the outcome of sporadic HEV infection during pregnancy. The explanation for this difference is not clear but may have to do with differences in viral load, with possibly higher viral load being present in patients infected during epidemics of HEV.

Why acute HEV infection in pregnant women causes severe liver dysfunction is not known. Poor nutritional status in these patients is often suggested as one of the major contributory factors, although no scientific proof is available. A lowered nutritional status lowers immune function, which may already be lowered in pregnancy (19). It is suggested that the increase in severity of viral hepatitis during pregnancy may be dependent on the geographical location of the patient in an underdeveloped area (20), as a higher susceptibility to fulminant hepatitis has not been noted in pregnant women in the developed world (21). A possibly poor nutritional status is suggested in our patients by the quite low serum albumin values observed.

Viral factors are also likely to be major determinants of disease severity. In pregnancy, especially late pregnancy, viruses are more likely to spread rapidly, attain high titers in tissues and produce more severe disease. For example, a study of Lassa fever in pregnant women found extremely high titers of the virus in placental tissue, suggesting that the placenta may be a preferred site of viral replication (22). It may be that such a situation also exists in HEV infection during pregnancy. If this was shown to be the case, early delivery in women with hepatitis $\mathrm{E}$ would be indicated. Studies which precisely measure risk factors for the severity of HEV in pregnancy are clearly required.

In conclusion, in the regional setting our main aim in pregnant women with FHF should be the accurate and rapid diagnosis of acute HEV infection. AFLP in any case is thought to be a rare cause of severe liver dysfunction (23) and, in the final analysis, none of our patients probably had AFLP. Therefore in countries like Pakistan and other parts of the world where $\mathrm{HEV}$ is endemic, the availability of reliable serological tests for this virus would be of great help to clinicians. We recommend that pregnant women with suspected viral hepatitis be admitted to hospital immediately as a number of them may progress to FHF. Although these patients rapidly develop fulminating disease, the overall prognosis is encouraging. Meticulous intensive care is likely to be very rewarding and hence a challenge for the clinician. However, a separate set of indicators of poor prognosis in this group of patients needs to be determined in order to define the role of therapies like liver transplantation. There are currently no data to support early delivery in severe HEV infection, but this needs evaluation in future studies.

\section{References}

1. Van Dyke RW. The Liver in Pregnancy. In: Zakim D, Boyer TD, eds. Hepatology, 2nd edn. Philadelphia; WB Saunders, 1990: 1438-59.

2. Malkani PK, Grewal AK. Observations on infectious hepatitis in pregnancy. Indian J Med Res 1957; 45 (suppl 1): 77-84.

3. Khuroo MS, Teli MR, Skidmore S. Lofo MA, Khuroo MI. Incidence and severity of viral hepatitis in pregnancy. Am J Med 1981; 70: 252-5.

4. Ramalingaswami V, Purcell RH. Waterborne non-A, non-B hepatitis. Lancet 1988; i: 571-3.

5. Burroughs AK, Leong NH, Dojcinov DM, Scheuer PJ, Sherlock SVP. Idiopathic acute fatty liver of pregnancy in 12 patients. Q J Med 1982; 204: 481-95.

6. Reyes H, Sandoval L, Wainstein A, Ribalta J, Donoso S, Smok G, Rosenberg H, Meneses M. Acute fatty liver of pregnancy: a clinical study of 12 episodes in 11 patients. Gut 1994; 35: 101-6.

7. Rolfes DB, Ishak KG. Acute fatty liver of pregnancy: a clinico-pathological study of 35 cases. Hepatology 1985; 5: 1149-58. 
8. Bernuau J, Rueff B, Benhamou JP. Fulminant and subfulminant liver failure: definitions and causes. Semin Liver Dis 1986; 6: 97-106.

9. Trey C, Davidson LS. The management of fulminant hepatic failure. In: Popper H, Schaffner F, eds. Progress in Liver Disease. New York: Grune and Stratton, 1970: 282-98.

10. Beach MJ, Meeks EL, Mimms LT, Vallari D, Ducharme L, Spelbring J, Taskar S, Schleicher JB, Krawczynski K, Bradley DW. Temporal relationships of hepatitis $\mathrm{C}$ virus RNA and antibody responses following experimental infection of chimpanzees. J Med Virol 1992; 36: 226-37.

11. Favarov MO, Khudyakov YE, Fields HA, Khudyakova NS, Padhya N, Alter MJ, Mast E, Polish L, Yashina TL, Yarasheva DM, Onischenko GG, Margolis HS. Enzyme immunoassay for the detection of antibody to hepatitis $E$ virus (anti-HEV) based on synthetic peptides. J Virol Methods 1993; 46: 237-50.

12. Favorov MO, Fields HA, Purdy MA, Yashina TL, Aleksandrov AG, Alter MJ, Yarasheva DM, Bradley DW, Margolis HS. Serologic identification of hepatitis $E$ virus infections in epidemic and endemic settings. J Med Virol 1992; 36: 24650.

13. Khuroo MS. Study of an epidemic of non-A, non-B hepatitis: possibility of another human virus distinct from post-transfusion non-A, non-B type. Am J Med 1980; 68: 818-23.

14. Davies MH, Wilkinson SP, Hanid MA, Portmann B, Brudenell JM, Newton JR, Williams R. Acute liver disease with encephalopathy and renal failure in late pregnancy and the early puerperium: a study of 14 patients. Br J Obstet Gynaecol 1980; 87: 1005-14.

15. Mckee CM, Weir PE, Foster JH, Murnaghan GA, Callender ME. Acute fatty liver of pregnancy and diagnosis by computed tomography. Br Med J 1986; 292: 291-2.

16. Tsarev SA, Emerson SU, Reyes GR, Tsareva TS, Letgers LJ, Malik IA, Iqbal M, Purcell RH. Characterization of a prototype strain of hepatitis E virus. Proc Natl Acad Sci USA 1992; 89: 559-63.

17. Jafri W., Nahid S, Shah H, Abbas Z, Hamid S, Abid S, Khan H. Fulminant hepatic failure: clinical profile and outcome. Abstract IXth APASL Scientific meeting, Malaysia, 1994.

18. O'Grady JG, Alexander GJM, Hayllar KM, Williams R. Early indicators of prognosis in fulminant hepatic failure. Gastroenterology 1989; 97: 439-45.

19. Lederman MM. Cell-mediated immunity and pregnancy. Chest 1984; 86: 6-95.

20. Borhanmanesh F, Haghigi P, Hekmat K, Rezaizadeh K, Ghavami $\mathrm{AG}$. Viral hepatitis during pregnancy: severity and effect on gestation. Gastroenterology 1973; 64: 304-12.

21. Adams RH, Combes R. Viral hepatitis during pregnancy. JAMA 1965; 192: 195-8.

22. McCormick JB, King IJ, Webb PA, Scribner CL, Craven RB, Johnson KM, Elliott LH, Belmont-Williams R. Lassa fever: effective therapy with ribavarin. $N$ Engl J Med 1986; 314 : $20-6$.

23. Pockros PJ, Peters RL, Reynolds TB. Idiopathic fatty liver of pregnancy: findings in ten cases. Medicine 1984; 63: 1-8. 